\title{
Dynamic sea-level change during the last deglaciation of northern Iceland
}

\author{
MATS RUNDGREN, ÓLAFUR INGÓLFSSON, SVANTE BJÖRCK, HUI JIANG AND HAFLIĐI HAFLIĐASON
}

BOREAS

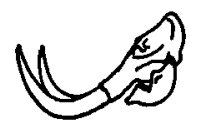

Rundgren, M., Ingólfsson, O., Björck, S., Jiang, H. \& Hafliðason, H. 1997 (September): Dynamic sea-level
change during the last deglaciation of northern Iceland. Boreas, Vol. 26, pp. 201-215. Oslo. ISSN $0300-9483$.

A detailed reconstruction of deglacial relative sea-level changes at the northern coast of Iceland, based on the litho- and biostratigraphy of lake basins, indicates an overall fall in relative sea level of about $45 \mathrm{~m}$ between 11300 and $9100 \mathrm{BP}$, corresponding to an isostatic rebound of $77 \mathrm{~m}$. The overall regression was interrupted by two minor transgressions during the late Younger Dryas and in early Preboreal, and these were probably caused by a combination of expansions of local ice caps and readvances of the Icelandic inland ice-sheet margin. Maximum absolute uplift rates are recorded during the regressional phase between the two transgressions $(10000-9850 \mathrm{BP})$, with a mean value of $c .15 \mathrm{~cm} \cdot{ }^{14} \mathrm{C}^{\mathrm{yr}}{ }^{-1}$ or $11-12 \mathrm{~cm} \cdot \mathrm{cal}$. $\mathrm{yr}^{-1}$. Mean absolute uplift during the regressional phase following the second transgression $(9700-9100 \mathrm{BP})$ was around $6 \mathrm{~cm}^{\cdot 14} \mathrm{C} \mathrm{yr}^{-1}$, corresponding to $c .3 \mathrm{~cm} \cdot \mathrm{cal}$. $\mathrm{yr}^{-1}$, and relative sea level dropped below present-day sea level at $9000 \mathrm{BP}$.

Mats Rundgren and Hui Jiang, Department of Quaternary Geology, Lund University, Tornavägen $13,5-22363$ Lund, Sweden; Olafur Ingólfsson, Earth Sciences Centre, University of Göteborg, S-413 81 Göteborg, Sweden; Svante Björk, Geological Institute, University of Copenhagen, Oster Voldgade 10, DK-1350 Copenhagen, Denmark; Haflidi Haflidason, Geological Institute, University of Bergen, Allégaten 41, N-5007 Bergen, Norway; received 8th August 1996, accepted 30th June 1997.
Raised beaches and marine terraces are common features along the coast of Iceland, indicating high relative sea level in connection with the last deglaciation. It was recognized early that this high sea-level stand was followed by a period with sea levels lower than at present (Bárðarson 1923), but it was not at that time possible to date this low-level event. Later studies of submerged peat deposits around the island have confirmed an event of low sea level (Thorarinsson 1956; Jónsson 1957; Th. Einarsson 1961), and radiocarbon dates (throughout this paper, BP refers to uncalibrated ${ }^{14} \mathrm{C}$ years) on submerged peat deposits in southwestern Iceland indicate that relative sea level fell below the present some time between 9500 and 9000 BP (Thorarinsson 1956; Kjartansson et al. 1964; Thors \& Helgadóttir 1991; Ingólfsson et al. 1995). Marine seismic reflection data from the same area (Thors \& Helgadóttir 1991), suggest that relative sea level was $30-35 \mathrm{~m}$ below the present level in the early Holocene. Similar data from Eyjafjörour, northern Iceland (Thors \& Boulton 1991) indicate that relative sea level in that area reached $-40 \mathrm{~m}$ in the Late Weichselian, followed by a transgression to $-20 \mathrm{~m}$ in the early Holocene.

In a recent paper, Ingólfsson et al. (1995) presented a stratigraphically controlled curve of relative sea-level displacement for southwestern Iceland. Their data suggest a fall in relative sea level of at least $45 \mathrm{~m}$ in the period $10300-9400 \mathrm{BP}$, corresponding to a mean absolute uplift rate of $6.9 \mathrm{~cm} \cdot{ }^{14} \mathrm{C} \mathrm{yr}^{-1}$. Ingólfsson $e t$ al. (1995) argued that this rapid uplift most likely can be ascribed to a combination of rapid Preboreal deglaciation and low asthenosphere viscosities below Iceland.
The purpose of the present investigation is to analyse in detail the uplift patterns connected with the deglaciation of northern Iceland using the well-established technique of reconstructing relative sea-level changes from isolated lake-basin stratigraphies (e.g. Hafsten 1960; Björck \& Digerfeldt 1982; Anundsen 1985). With this method it is possible to detect temporal variations in isostatic rebound during deglaciation and possibly identify shorter periods of subsidence, enabling a connection to advances of the Icelandic ice sheet.

The Skagi peninsula in northern Iceland (Fig. 1) was chosen as a suitable area for the investigation because (1) it carries numerous lakes at varying altitutes, (2) it is known to have been deglaciated relatively early, i.e. at least in the Allerød period (Björck et al. 1992; Rundgren 1995), (3) it displays a distinctive pollen stratigraphy, which can be used for correlation between lake successions (Rundgren 1995), and (4) it features a series of pronounced raised beach ridges indicating that the area has experienced earlier relative sea levels at least $65 \mathrm{~m}$ higher than at present (Moriwaki 1990).

\section{Methods}

Our strategy was to collect sediments from a number of lakes at varying elevations between the marine limit and present sea level, and then to use diatom analysis and lithostratigraphic methods to identify marine, brackish and freshwater phases in these sediment successions. If transitions between sedimentary environments could be dated, it would be possible to reconstruct relative sea-level changes in relation to 


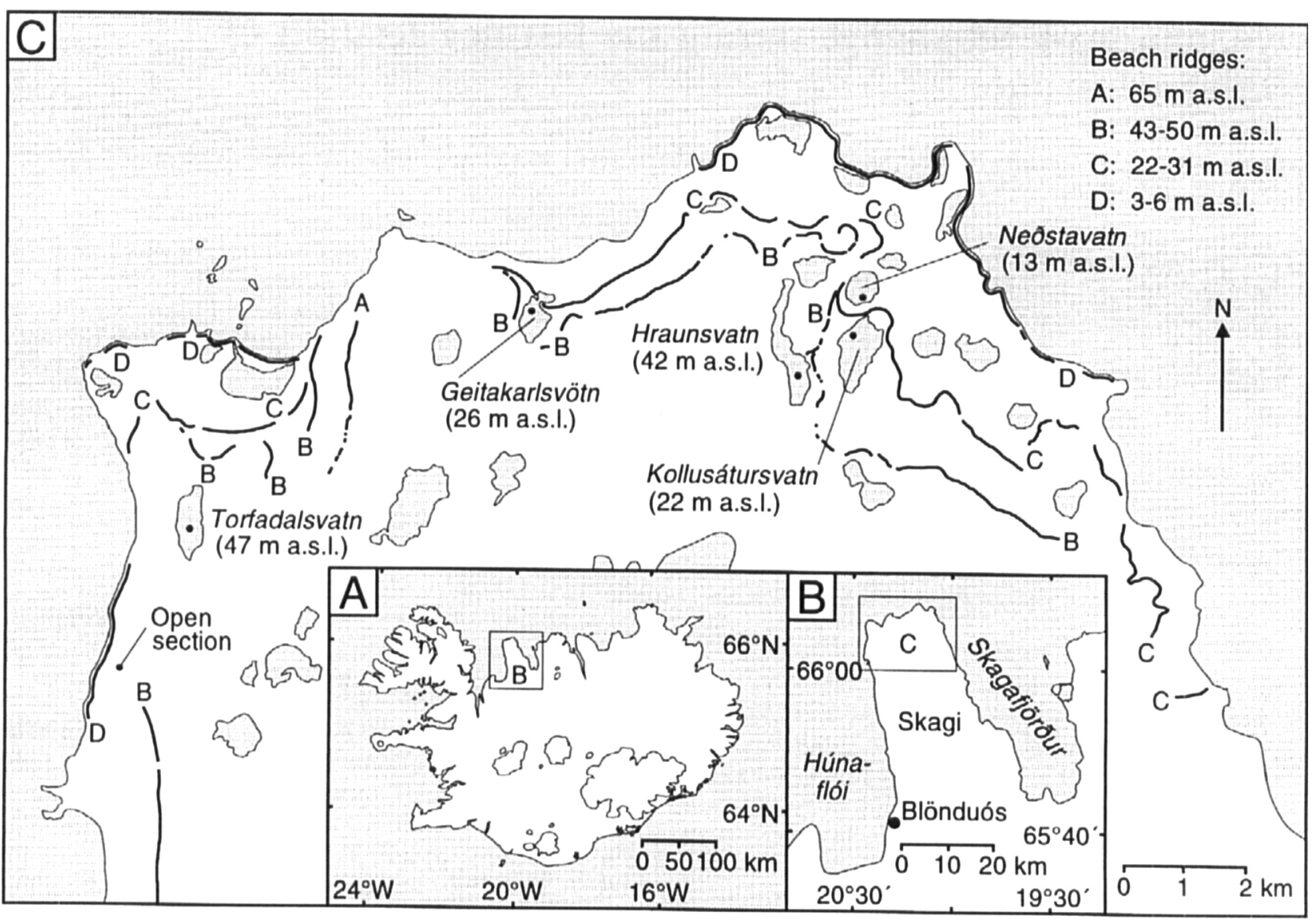

Fig. 1. $\sqcup$ A. Map of Iceland with present day glaciers. The area covered by the map in (B) is indicated. $\square$ B. Map of the Skagi peninsula and adjacent fjords. The area covered by the map in (C) is indicated. $\square$ C. Map of the northernmost part of the Skagi peninsula with the studied sites and mapped beach ridges. Dots within lakes mark coring sites.

lake thresholds and to produce a Late Weichselian and early Holocene sea-level displacement curve for northernmost Skagi.

\section{Mapping of raised beach ridges}

Raised beach ridges were identified on aerial photographs and levelled with reference to present sea level using a levelling instrument. We estimate the precision in our levellings to $\pm 0.2 \mathrm{~m}$. Taking into account a tidal amplitude of $1.5 \mathrm{~m}$, the general precision in our beach-ridge data is considered to be around $\pm 1 \mathrm{~m}$.

\section{Mapping and coring of lakes}

Five lake basins, situated at varying elevations below the highest identified raised beach ridge in the area $(65$ $\mathrm{m}$ a.s.1.), were selected (Fig. 1; Table 1). Lake thresholds, i.e. the critical elevations in relation to former relative sea levels, were levelled in the same way as the raised beach ridges. The resulting threshold levels are generally in accordance with the corresponding lake levels given by the topographic map pub- lished by Landmælingar Íslands, but in some instances there are considerable differences. In those cases we rely on our field data.

Coring was made from lake ice with Russian samplers of 5 and $10 \mathrm{~cm}$ width. One main core was collected from each basin, and the sediments were

Table I. The investigated sites.

\begin{tabular}{lllll}
\hline Site & Location & $\begin{array}{l}\text { Altitude } \\
(\mathrm{m} \text { a.s.l. })\end{array}$ & $\begin{array}{l}\text { Size } \\
\left(\mathrm{km}^{2}\right)\end{array}$ & $\begin{array}{l}\text { Water } \\
\text { depth at } \\
\text { coring } \\
\text { site }(\mathrm{m})\end{array}$ \\
\hline Lake Torfadalsvatn & $\begin{array}{l}66^{\circ} 04^{\prime} \mathrm{N}, \\
20^{\circ} 23^{\prime} \mathrm{W}\end{array}$ & 47 & 0.37 & 5.10 \\
Lake Hraunsvatn & $66^{\circ} 05^{\prime} \mathrm{N}$, & 42 & 0.48 & 0.90 \\
& $20^{\circ} 10^{\prime} \mathrm{W}$ \\
Lake Geitakarlsvötn & $66^{\circ} 05^{\prime} \mathrm{N}$, & 26 & 0.24 & 1.50 \\
& $20^{\circ} 16^{\prime} \mathrm{W}$ & & & \\
Lake Kollusátursvatn & $66^{\circ} 05^{\prime} \mathrm{N}$, & 22 & 0.51 & 1.50 \\
& $20^{\circ} 08^{\prime} \mathrm{W}$ \\
$66^{\circ} 06^{\prime} \mathrm{N}$, & 13 & 0.21 & 1.40 \\
Lake Neðstavatn & $20^{\circ} 08^{\prime} \mathrm{W}$ \\
$66^{\circ} 02^{\prime} \mathrm{N}$, & 1.5 & & \\
Open section & $20^{\circ} 25^{\prime} \mathrm{W}$ & & & \\
\hline
\end{tabular}


Table 2. Radiocarbon dates used in this study.

\begin{tabular}{|c|c|c|c|c|c|}
\hline $\begin{array}{l}\text { Depth below sediment } \\
\text { surface }(\mathrm{m})\end{array}$ & $\begin{array}{l}{ }^{14} \mathrm{C} \text { age } \\
(\mathrm{BP} \pm 1 \sigma)\end{array}$ & $\begin{array}{l}\text { Dated } \\
\text { material }\end{array}$ & $\begin{array}{l}\text { Type of } \\
\text { dating }\end{array}$ & Lab. no. & $\begin{array}{l}\text { Calibrated } \\
\text { age }^{2}(\mathrm{BP} \pm 1 \sigma)\end{array}$ \\
\hline \multicolumn{6}{|l|}{ Lake Torfadalsvatn } \\
\hline $7.620-7.630^{1}$ & $10550 \pm 240$ & bulk & AMS & Ua-1887 & $12640+250 /-300$ \\
\hline $7.315-7.325^{1}$ & $9470 \pm 200$ & bulk & AMS & Ua-1888 & $10640+450 /-200$ \\
\hline $7.215-7.225^{1}$ & $9890 \pm 290$ & bulk & AMS & Ua-1889 & $11220+900 /-200$ \\
\hline $7.040-7.070$ & $9530 \pm 210$ & bulk & conv. & Lu-3730 & $10730+400 /-250$ \\
\hline $7.050^{1}$ & $9180 \pm 210$ & mosses & AMS & Ua-1890 & $10360+300 /-200$ \\
\hline \multicolumn{6}{|l|}{ Lake Geitakarlsvötn } \\
\hline $4.950-4.988$ & $10060 \pm 200$ & bulk & conv. & Lu-3957 & $11650+600 /-450$ \\
\hline $4.430-4.460$ & $9570 \pm 180$ & bulk & conv. & Lu-3958 & $10800+350 /-250$ \\
\hline
\end{tabular}

'Date from core A1 (Björck et al. 1992) lithostratigraphically correlated to core B1 used in this study.

${ }^{2}$ According to Björck et al. (1996) with approximated $\sigma$ values.

described immediately after retrieval. As regression below present sea level has been shown to have occurred prior to $9000 \mathrm{BP}$ in other parts of Iceland, we were only interested in sediments deposited up to that time. This level was easily located in all lakes due to the presence of the Saksunarvatn ash, dated to $c .9000$ BP (Mangerud et al. 1986; Björck et al. 1992; Birks et al. 1996). This tephra was recorded as a thick $(\geq 14$ $\mathrm{cm}$ ), black and silty deposit that was hard to penetrate.

The Saksunarvatn ash was also found in an open section at c. $1.5 \mathrm{~m}$ a.s.l. (Table 1, Fig. 1), which made it possible to get a stratigraphic record from an altitude below the lowest cored lake, close to present sea level. Consequently, we were able to test whether regression below present sea level really took place before $9000 \mathrm{BP}$ in this area.

\section{Diatom analysis}

A total of 80 samples from the lake sequences and one from the open section were analysed for diatoms. They were all treated with $10 \% \mathrm{HCl}$, washed with distilled water, and treated with $30 \% \mathrm{H}_{2} \mathrm{O}_{2}(1-2 \mathrm{~h}$ in a water bath at $60^{\circ} \mathrm{C}$ ). More than 300 valves were counted in each sample, although at some levels the limited preservation and/or low concentration of diatoms in the sediments prevented reaching this number.

We applied the diatom taxonomy and ecological information given by Hendey (1964), Hustedt (19301959), Krammer \& Lange-Bertalot (1986-1991) and Patrick \& Reimer (1966-1975), and grouped the species with regard to their salinity preferences according to the halobian system of Hustedt (1957), originally proposed by Kolbe (1927): Marine species = polyhalobous $(>30 \%)$, brackish species $=$ mesohalobous $(30-0.2 \%)$, freshwater species $=$ oligohalobous $($ halophile, indifferent) and halophobous $(<0.2 \% 0)$. Fragilaria species were not included in the diatom sum and the halobian spectrum because of their mass occurrences.

\section{Lithostratigraphic studies}

We used SIRM (saturation isothermal remanent magnetization) as a rough estimate of grain size and organic carbon content as a measure of organic sedimentation (autochthonous and allochthonous). Coarse-grained, minerogenic horizons often mark transgressions and regressions of a basin threshold (Björck 1981), and productivity is usually higher in closed basins due to less suspended matter and higher temperatures (Berglund 1966). SIRM was measured on contiguous $22-\mathrm{mm}$ subsamples previously magnetized in a field of $1 \mathrm{~T}$, and the induced remanent magnetizations were measured on a 'Minispin' magnetometer. In order to obtain representative estimates of organic sedimentation, all visible tephra horizons were avoided during subsampling for carbon analysis. To enable separation of carbonate from organic carbon, we combusted all samples in a Leco RC-412 Multiphase Carbon Determinator from $100^{\circ}$ to $950^{\circ} \mathrm{C}$ at a ramp rate of $50^{\circ} \cdot \mathrm{min}^{-1}$.

\section{Dating}

We applied the chronology established for our Lake Torfadalsvatn core (here named B1) by Rundgren (1995), and used pollen-stratigraphic correlation to transfer it to the other lake successions. The chronology of Rundgren (1995) was based on five radiocarbon dates from core $\mathrm{B} 1$ and another core (here named Al) from the same lake (Björck et al. 1992; Table 2), together with the location of the Vedde and Saksunarvatn ashes. These tephras are dated to $c$. $10300 \mathrm{BP}$ (Bard et al. 1994; Birks et al. 1996) and c. 9000 BP (e.g. Birks et al. 1996) respectively, and their possible occurrence in the other lake successions would improve our chronologies. Additional radiocarbon dates were obtained from the Lake Geitakarlsvötn sequence (Table 2). As no carbonate was detected by the carbon analysis, there is no hard-water effect on bulk sediment dates from the studied lakes.

In addition to the obtained ${ }^{14} \mathrm{C}$ chronology, we sought to relate the sea-level events of each basin to 
calendar years BP (AD 1950). This is done according to the recent synchronization between ${ }^{14} \mathrm{C}$-dated tree rings and lake sediments, and the GRIP ice-core chronology (Björck et al. 1996). In practice, this means that 161 years are added to the calendar years of the pine-based part of the present calibration (Stuiver \& Reimer 1993), and the few dates further back in time we tentatively date with the 75-yr reduced GRIP chronology (Björck et al. 1996). Because of the occurrences of both extensive ${ }^{14} \mathrm{C}$-plateaux and periods with rapidly falling ${ }^{14} \mathrm{C}$ ages, some age determinations are less exact and contain a certain element of interpretation. We assign the new calendar ages to a few important synchronous events, such as the Allerød/ Younger Dryas and Younger Dryas/Preboreal boundaries, the Vedde Ash and the Saksunarvatn ash and some distinct Preboreal events (Björck et al. 1996), the last-mentioned correlated to similar events in northern Iceland (Björck et al. in press; Table 3), and then use the calendar ages of these events to relate the sea-level events of each basin to calendar years.

Pollen analysis and correlation. - In addition to pollen and spores, we also counted coenobia of the green algal genus Pediastrum. All preparations and identifications were made according to the procedure described by Rundgren (1995). Many samples turned out to be even poorer in pollen content than those earlier analysed from Lake Torfadalsvatn (Rundgren 1995), and pollen sums are very low at some levels. Owing to the resulting variation in pollen sum within and between successions, we prefer to present our pollen-stratigraphic data as concentrations instead of percentages.

Correlations between pollen stratigraphies were partly based on the results from a principal components analysis (PCA) of the pollen data, including the Lake Torfadalsvatn samples analysed by Rundgren (1995). The total number of samples was 92, but as we regard percentage values calculated on sums lower than 40 pollen to be unreliable, our PCA correlations are only based on the ordination of a percentage data set consisting of 56 samples (terrestrial pollen sum $\geq 40$ ) and 37 taxa. By visual inspection of joint plots of the sample scores for each new lake together with the sample score range covered by the Lake Torfadalsvatn local pollen assemblage zones (LPAZs), it

Table 3. Synchronous events used to assign calendar ages to sealevel events in the studied sequences.

\begin{tabular}{ll}
\hline Event & Calibrated age (BP) \\
\hline Allerod/Younger Dryas boundary & 12600 \\
Vedde Ash & 11865 \\
Younger Dryas/Preboreal boundary & 11450 \\
RPAZ Skagi-4/Skagi-5 boundary & 10800 \\
Saksunarvatn ash & 10065 \\
\hline
\end{tabular}

' According to Björck et al. (1996). was possible to combine samples and form corresponding LPAZs for the other lakes. A few samples could not be assigned to LPAZs solely on the ordination of the pollen data set. For these samples we used additional data such as Pediastrum, limno-phyte and terrestrial concentration values, organic carbon content and lithostratigraphy as a basis for our correlations.

Tephra analysis. - All potential tephra horizons recorded during visual inspections of the sediment cores were subsampled for tephrostratigrahic analysis. Segments of these potential tephra horizons were suspended in water and wet-sieved through $63 \mu \mathrm{m}$ and $125 \mu \mathrm{m}$ sieves. After digestion of organic material with $\mathrm{H}_{2} \mathrm{O}_{2}$, the remaining glass shards were subjected to chemical analysis. For the Lake Torfadalsvatn (core B1) samples we used a standard wavelength dispersal (EMP) technique, while the samples from the other studied lakes were analysed on a scanning electron microscope connected to an energy dispersive spectrometer (SEM).

\section{Results}

\section{Raised beach ridges}

Three sets of prominent raised beaches at 65 (A), 43-50 (B) and 22-31 (C) m a.s.l. were mapped along the northern coast of Skagi (Fig. 1). Moriwaki (1990) studied the same ridges in the western part of the area and levelled the highest ridge (A) to $52.5 \mathrm{~m}$ a.s.l. Our mapping shows that the two lower ridges (B and C) are almost continuous along the coast. Therefore, their spatial relation to the investigated lake basins enables correlation between synchronous sea-level phases registered in the lake sediments.

Little is known about the direction of isobases in Iceland, but they are generally assumed to parallel the outline of the former ice sheet (Th. Einarsson 1961, 1963). Hence, they are also more or less parallel to the present coastline, at least in the south. In northern Iceland, however, the coastline is characterized by broad fjords and peninsulas. Raised beach ridges and terraces along these fjords are often inclined towards the south, indicating higher uplift rate in the interior compared to the outer coast ( $\mathrm{Tr}$. Einarsson 1959; Th. Einarsson 1963; Ingólfsson 1991). The magnitude of the observed differences in altitude within ridge B (7) $\mathrm{m})$ and $\mathrm{C}(9 \mathrm{~m})$ suggests that some tilt may be present in these ridges, but our attempts to reconstruct isobases from the altimetric data were inconclusive. This can partly be explained by considerable altitudinal variability within individual ridges due to local differences in topography and fetch on this high-energy coast. We observed altitudinal variations of the order of a few metres over short distances, and the 


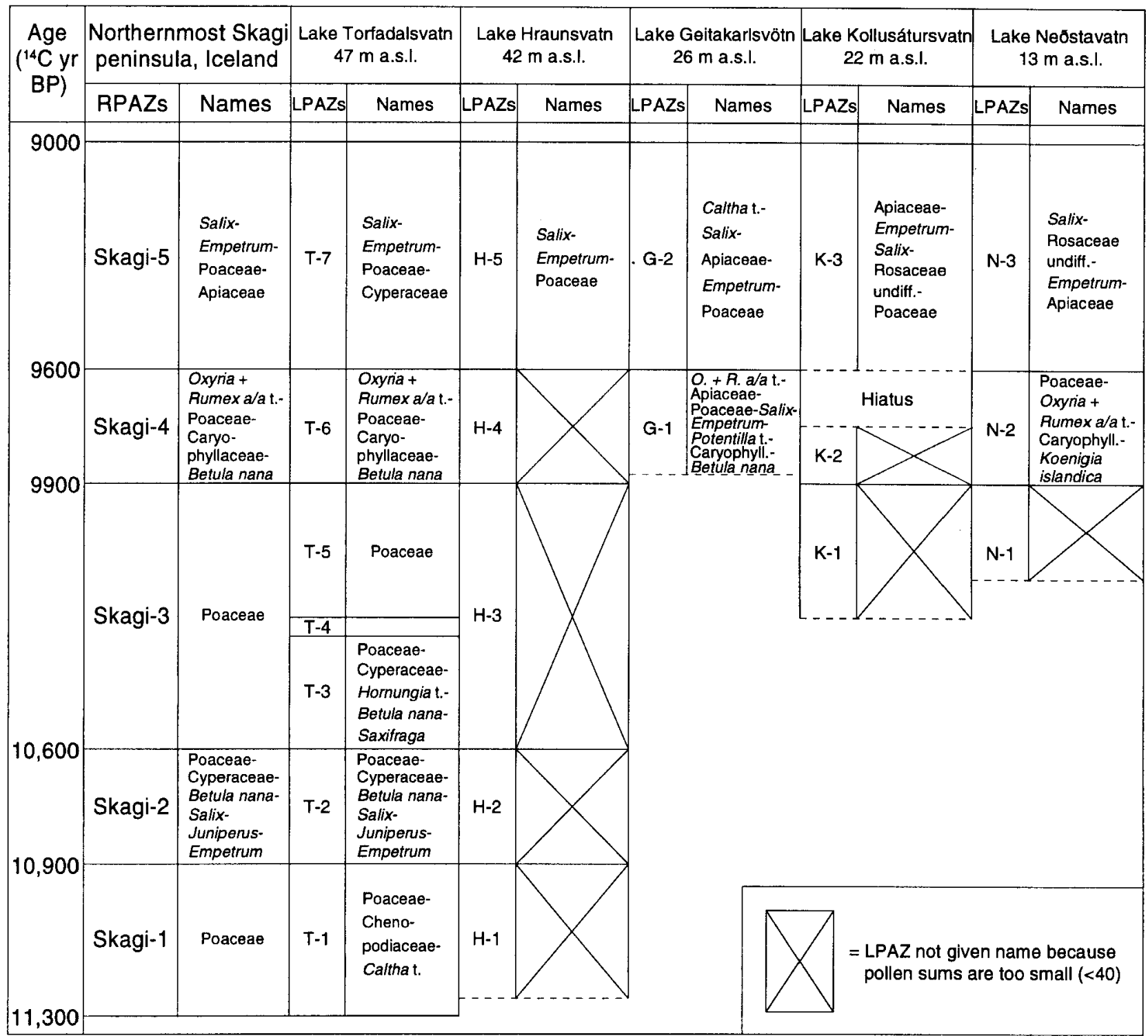

Fig. 2. Correlations between the proposed local pollen assemblage zones (LPAZs) and those earlier defined for the Lake Torfadalsvatn sequence by Rundgren (1995), together with the regional pollen assemblage zones (RPAZs) proposed for northernmost Skagi. Note that the T-6/T-7 boundary is redated to 9600 BP (cf. Rundgren 1995).

recent beach ridge (D) was found to vary in height from 3 to $6 \mathrm{~m}$ a.s.l. These altitudinal uncertainties, in combination with a small geographical spread of the altimetric data, are the likely causes behind our unsuccessful isobase reconstructions. Therefore, we can only assume that the isobases along the northern coast of the Skagi peninsula are oriented in an east-westerly direction, i.e. more or less parallel to the mapped beach ridges. However, oblique isobase trends to the present coastline for ridges $B$ and $C$ cannot be ruled out.

\section{Chronology}

All pollen-stratigraphic correlations, together with defined regional pollen assemblages zones (RPAZs), are shown in Fig. 2. As no equivalent to zone T-4 was identified in any of the new sequences, the proposed redeposition of this zone (Rundgren 1995) was confirmed.

Delimitation of the LPAZs corresponding to RPAZs Skagi-4 and Skagi-5 in Lake Geitakarlsvötn only from the PCA analysis was problematic. We 

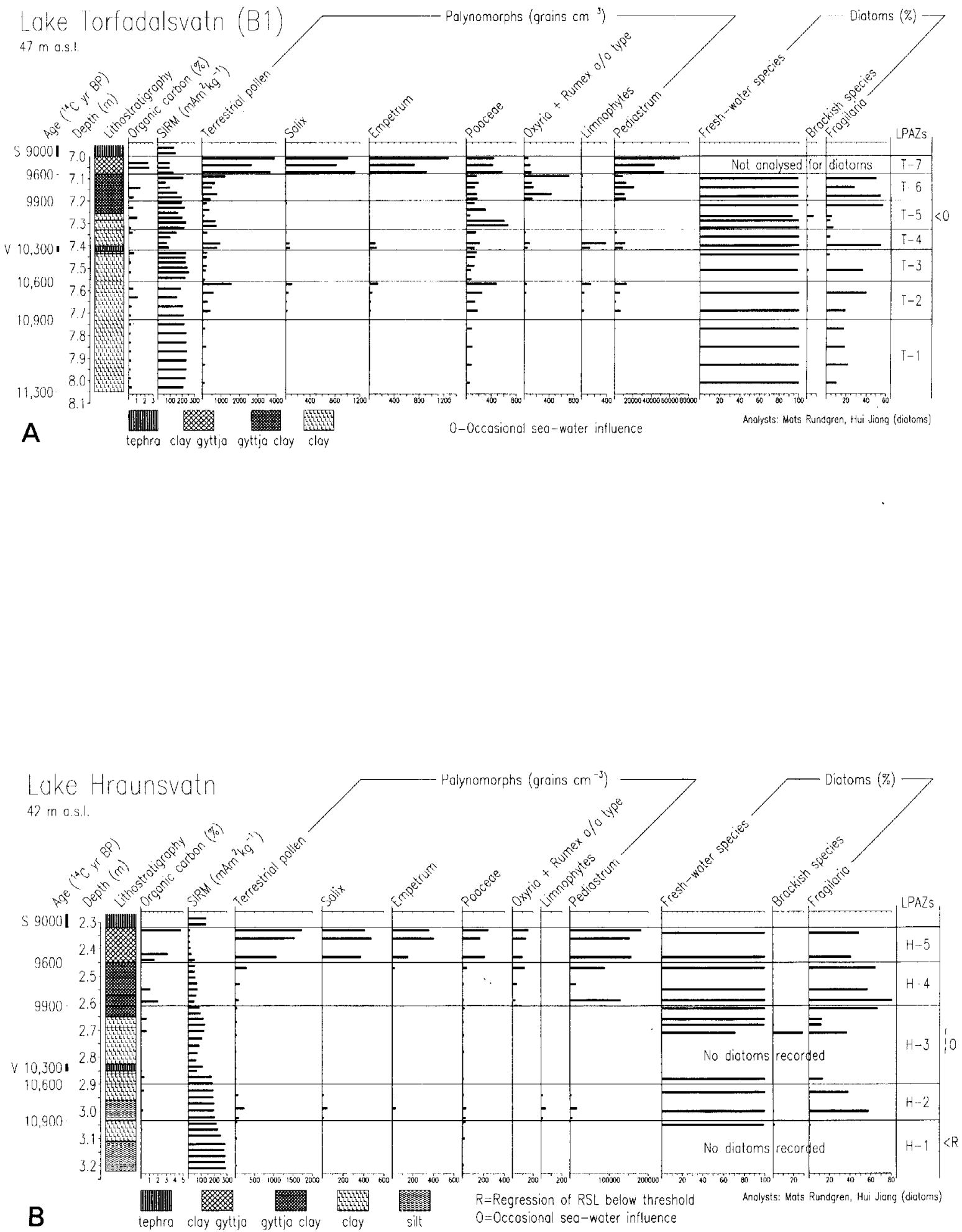

Fig. 3. $\square$ A E. Combined diagrams for the five investigated lake sequences showing chronology, lithostratigraphic parameters, palynomorphs, diatoms, and inferred relations between basin thresholds and relative sea level (RSL). The assigned ages refer to the pollen assemblage zone boundaries defined in Fig. 2 and the ages of the Vedde Ash (V) and Saksunarvatn ash (S) tephras (Bard et al. 1994; Birks et al. 1996). In addition, two radiocarbon dates from Lake Geitakarlsvötn are shown in (C). Diatom frequencies are presented as percentages of the diatom sum excluding Fragilaria, while Fragilaria frequencies are based on the total sum. 

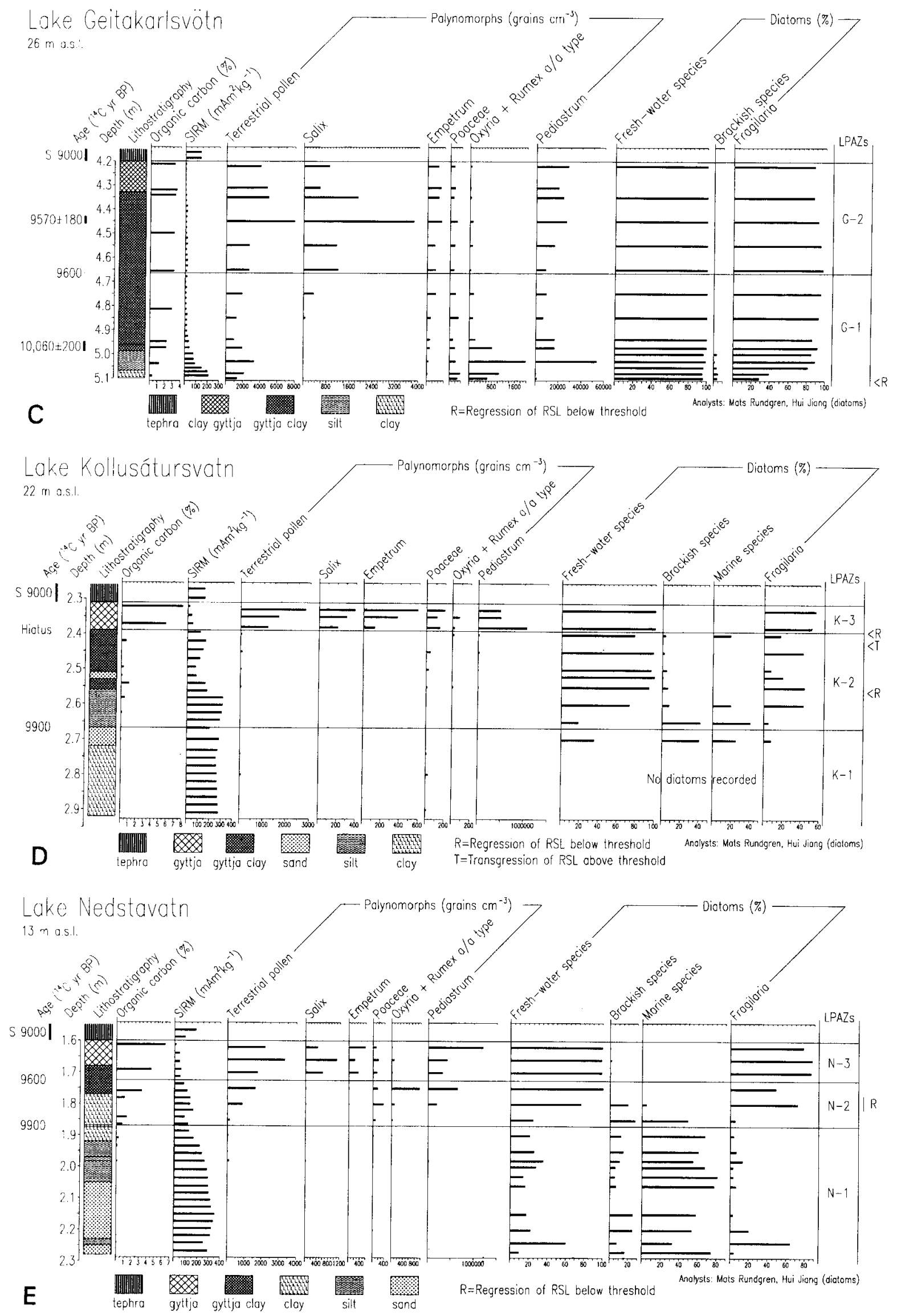
have chosen to place the $\mathrm{G}-1 / \mathrm{G}-2$ boundary at 4.665 $\mathrm{m}$ (Fig. 3C). At this level, the concentrations of Oxyria + Rumex a/a type pollen grains have returned to low values, and there are still relatively low concentrations of Salix and Empetrum pollen. Moreover, terrestrial pollen and Pediastrum concentration values start to rise around this level, which is indicative of the transition into RPAZ Skagi-5 in the other successions. The radiocarbon date of $9570 \pm 180 \mathrm{BP}$ (Table 2) from above the Skagi-4/Skagi-5 boundary suggests that the previous age of 9400 BP for this boundary (Rundgren 1995) is too young. This is also indicated by a bulk sediment date of $9530 \pm 210 \mathrm{BP}$ (Rundgren 1995) at the same stratigraphic level in Lake Torfadalsvatn (Table 2). These two radiocarbon dates, in spite of their relatively great standard errors, together suggest that the Skagi-4/Skagi-5 boundary is older than $9500 \mathrm{BP}$. i.e. it is dated to the beginning of the $96009400{ }^{14} \mathrm{C}$ plateau (Kromer \& Becker 1993). Therefore, it is possible to define this pollen-zone boundary, and we redate it to c. $9600 \mathrm{BP}$ (Fig. 2).

From the pollen stratigraphy (Fig. $3 \mathrm{C}$ ), it is clear that the Lake Geitakarlsvötn sequence does not extend down into the Younger Dryas, i.e. it is not older than $10000-9900$ BP. An additional radiocarbon date from close to the base of the core was dated to $10060 \pm 200 \mathrm{BP}$ (Table 2). Owing to an extensive ${ }^{14} \mathrm{C}$ plateau within the age interval in question (Kromer \& Becker 1993), precise radiocarbon dating is impossible. Considering the pollen stratigraphy, we estimate the age of the base of the Lake Geitakarlsvötn succession to be situated at the end of the $10000-9900{ }^{14} \mathrm{C}$ plateau, which corresponds to the beginning of the Preboreal (Björck et al. 1996).

Zonation of the Lake Kollusátursvatn succession was partly problematic since Oxyria-dominated RPAZ Skagi-4 is poorly expressed in this lake (LPAZ $\mathrm{K}-2$; Fig. 3D). The presence of a hiatus at $2.39 \mathrm{~m}$ is suggested by a sharp and inclined lithological boundary and coincident abrupt changes in both pollen and diatom assemblages. The hiatus may be the result of non-sedimentation and erosion due to a higher energy level in the lake induced by the marine ingression recorded in the sample below. Consequently, the marine sediments of the upper part of RPAZ Skagi-4 are missing in Lake Kollusátursvatn. Sedimentation was probably resumed following the subsequent isolation.

Onc sample (A) from the open section, taken at 1.5 $\mathrm{cm}$ below the Saksunarvatn ash, within a thin peat bed, was analysed for pollen (Fig. 4, Table 4). The presence of Salix and Empetrum clearly shows that the sample belongs to RPAZ Skagi-5, i.e. it is dated to some time between 9600 and $9000 \mathrm{BP}$. The concentration values for dwarf shrubs, in particular Salix, are low compared with those found in the lake sequences, which is not surprising since the peat sample represents pollen deposition in a fen. This is also indicated
Table 4. Results of the pollen and diatom analysis of sample $\mathrm{A}$ from the open section.

\begin{tabular}{lc}
\hline Palynomorphs & grains $\cdot \mathrm{cm}^{-3}$ \\
\hline Terrestrial pollen & 29852 \\
Salix & 30 \\
Empetrum & 985 \\
Poaceat & 16001 \\
Oxyria + Rumex a/a type & 60 \\
Pediastrum & - \\
\hline Diatoms & $11 / 9$ \\
\hline Freshwater species & 100 \\
Fragilaria & 35 \\
\hline
\end{tabular}

by the high Poaceae pollen concentration value and absence of Pediastrum. The extremely high concentration of Cyperaceae pollen (16 times higher than in any of the lake sequences) suggests that the peat was deposited in a sedge fen. From its position in relation to the Saksunarvatn ash, taking into account a normal growth rate for Icelandic fen peat of 0.02-0.03 $\mathrm{cm} \cdot \mathrm{yr}^{-1}$ (Th. Einarsson 1961; Hallsdóttir 1987), we date sample A to $c .9050 \mathrm{BP}$.

The identification of the Vedde Ash in the Lake Torfadalsvatn and Lake Hraunsvatn sequences (Figs. 5 and $3 \mathrm{~A}-\mathrm{B})$, together with the chemical confirmation of the Saksunarvatn ash in all investigated lake sequences and the open section (Figs. 3A-E, 4, and 5), further improved the resolution of our chronologies. The absence of the Vedde Ash in the other sediment sequences, despite efforts to locate it, suggests that those cores do not extend back to $10300 \mathrm{BP}$.

\section{Reconstructions of relative sea level}

Lake Torfadalsvatn. - There is no trace of any marine influence in the sequence (Fig. 3A). This indicates that

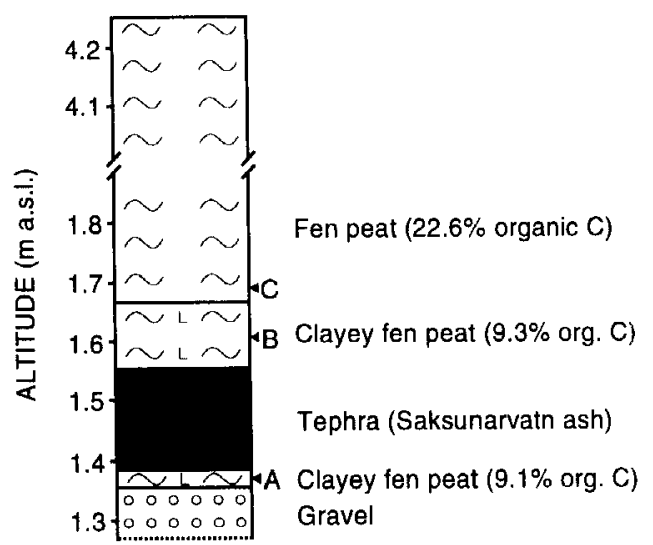

Fig. 4. Stratigraphy of the open section with the position of the analysed samples. Sample A was analysed for organic carbon. pollen and diatoms (Table 1), while only the organic carbon content was determined in samples $B$ and $C$. 


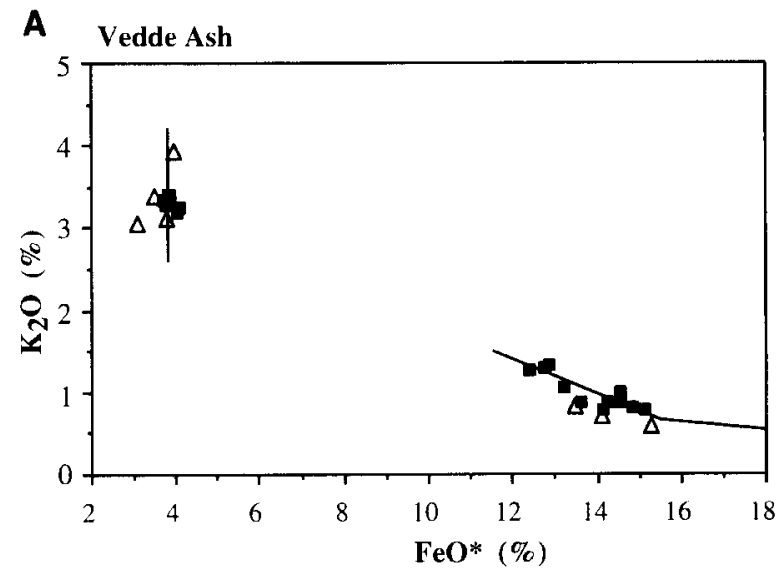

B

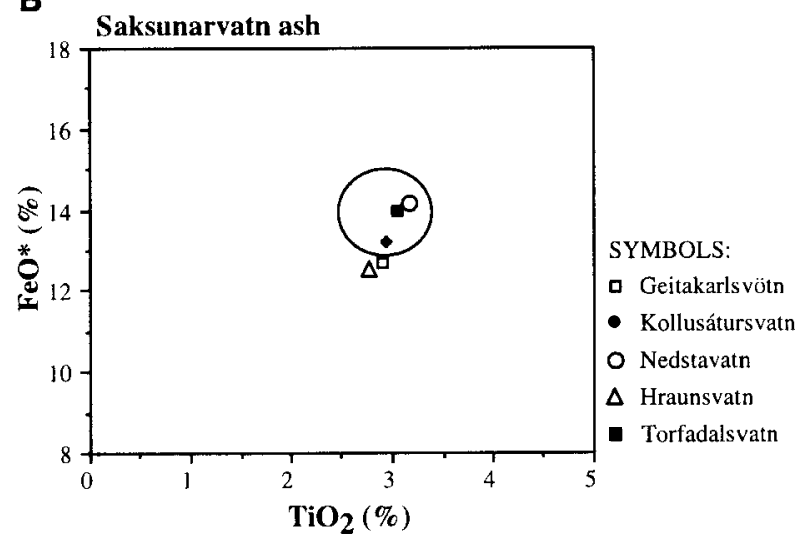

Fig. 5. Geochemical characterization of the key tephra horizons in the lakes studicd, using an electron microprobe (Lake Torfadalsvatn samples) and a scanning electron microscope connected to an energy dispersive spectrometer (samples from the other lakes studjed). The analyses have been normalized to $100 \%$ by weight. The locations of the samples are shown in Fig. 3. ${ }^{-}$A. Vedde Ash. Estimates of $\mathrm{FeO}^{*}$ and $\mathrm{K}_{2} \mathrm{O}$. Lines show the highest frequency of distribution previously determined for the rhyolitic and the basalticintermediate populations (Mangerud et al. 1986; Kvamme et al. 1989). [" B. Saksunarvatn ash. Estimates of $\mathrm{FeO}^{*}$ and $\mathrm{TiO}_{2}$. The plots show the mean values for the Saksunarvatn tephra horizon in the lakes studied. The encircled area marks the main chemical distribution of the Saksunarvatn ash population (Mangerud et al. 1986: Ingólisson et al. 1995).

the basin was isolated from the sea by $11300 \mathrm{BP}$ (13000 cal. yr BP), which is the estimated age for the core bottom (Rundgren 1995). There is, however, a short interval with a relatively high frequency of the brackish diatom species Surirella brebissonii within LPAZ T-5. In a small lake like this, the most probable interpretation of this type of diatom assemblage, dominated by freshwater species and with a minor brackish element. is that the lake was situated close to the seashore and subjected to occasional inflow of sea water or sea spray in connection with extreme tide or storms. This slightly brackish event is confined to a 3 -cm thick, blue-grey clay unit with an abnormally low pollen concentration value, which indicates that it was deposited under different sedimentary conditions compared to the rest of the sequence. This event of sea-water influence occurred at some time between the deposition of the Vedde Ash and the T-5/T-6 boundary, i.e. around 10100 BP (1 $1600-11500$ cal. yr BP).

Lake Hraunsvatn. - Marine diatoms are absent throughout the sequence, and no diatoms at all could be found at the base of the core (Fig. 3B). Since no fragmented frustules were observed in the samples, this barren zone cannot be attributed to reworking of the sediments. We have no explanation for the absence of diatoms, but it may reflect that living conditions were harsh in the basin. The presence of some brackish diatoms at $3.05 \mathrm{~m}$ suggests, as in the case of Lake Torfadalsvatn, that the lake was near the seashore. Accordingly, we interpret the sediments below $3.05 \mathrm{~m}$ to be deposited in connection with basin isolation, when relative sea level was lowered below the threshold. Isolation was completed prior to the $\mathrm{H}-1 / \mathrm{H}-2$ boundary, i.e. shortly before $10900 \mathrm{BP}$ (12 700 cal. yr BP), whereafter the diatom record reflects freshwater conditions. At the base of the overlying silt unit, around $3.03 \mathrm{~m}$, there is a gravelly horizon, indicating that wave action still could influence the basin. Consequently, relative sea level did not fall far below the basin threshold in the period following isolation.

Another section without diatoms occurs within zone $\mathrm{H}-3$, and the succeeding sample at $2.71 \mathrm{~m}$ shows a significant frequency of Achnantes delicatula (29\%), a brackish species including many varieties. Its abundance suggests occasional inflows of sea water at that level, similar to the situation in the slightly brackish phase in the Lake Torfadalsvatn sequence. These conditions may have arisen already in the upper part of the barren zone around $10200 \mathrm{BP}$ (11 $800 \mathrm{cal}$. yr BP), and they ceased around $10000 \mathrm{BP}$ (11 500 cal. yr BP).

Lake Geitakarlsvötn. - The entire sediment sequence is clearly deposited in a freshwater environment (Fig. $3 \mathrm{C}$ ), but the presence of some brackish diatom species ( $\max .5 \%$ ) in the lowermost five samples indicates that the basin was close to the sea when the basal sediments were deposited. This interpretation is supported by the presence of some sand and gravel, that could be related to threshold erosion, in the lowermost clay unit. According to our age estimate for the basal sediments, the lake was isolated at c. 9900 BP (11 350 cal. yr BP).

Lake Kollusátursvatn. - No diatoms were found in the lowermost part of the sequence (Fig. 3D). The subsequent three samples show a significant content of brackish and marine diatoms, and a transition to freshwater conditions occurs at $2.56 \mathrm{~m}$, above the $\mathrm{K}-1 / \mathrm{K}-2$ boundary. We place the isolation at $9850 \mathrm{BP}$ 


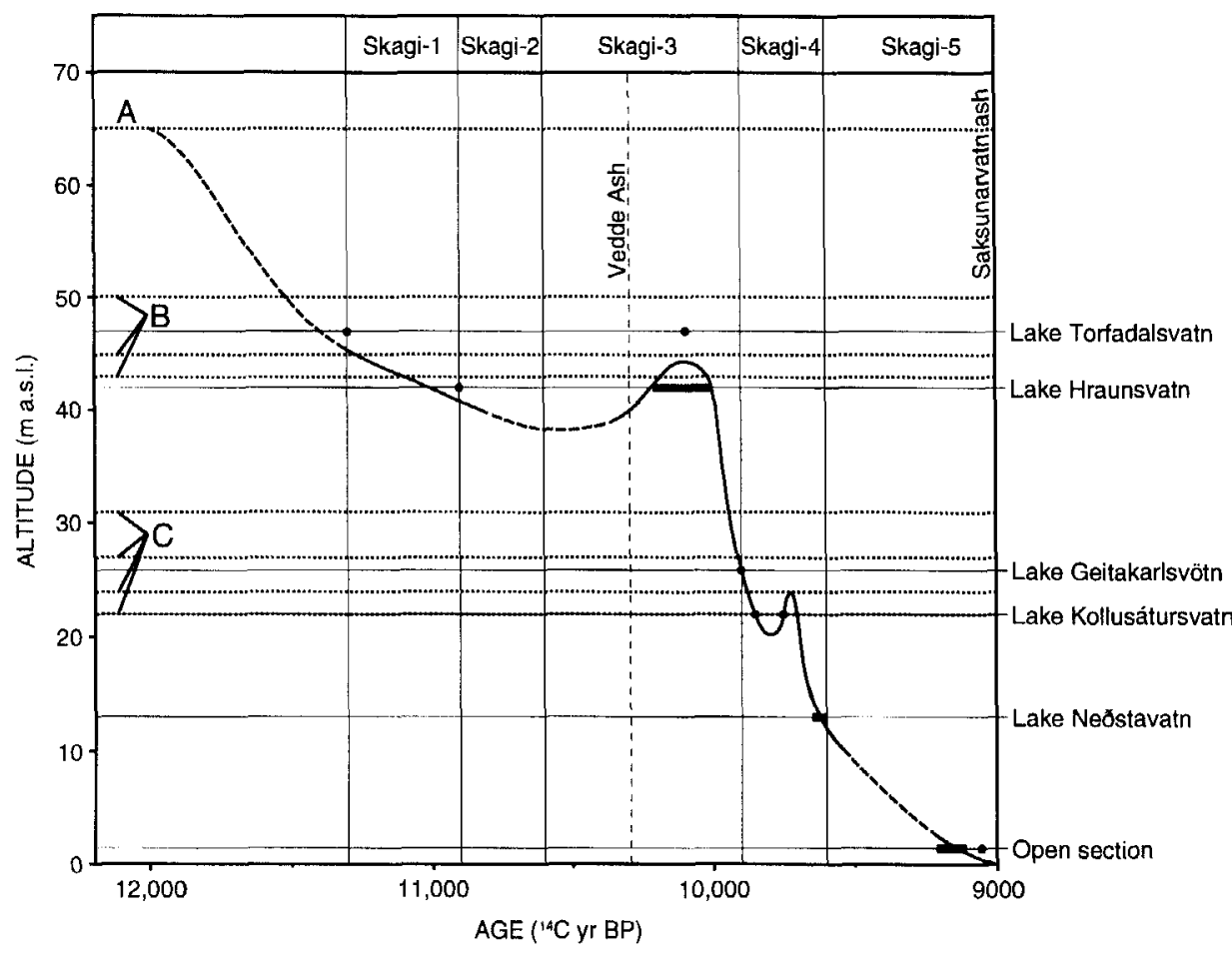

Fig. 6. Tentative ${ }^{14} \mathrm{C}$-yearbased relative sea-level curve for northernmost Skagi. The curve was fixed by each site's discussed sea-level history, marked by dots and horizontal bars. The altitudes of the studied sites are shown as horizontal solid lines, and the mapped raised beach ridges (A-C) as horizontal dashed lines. The regional assemblage pollen zones defined in Fig. 2 are shown at the top of the figure.
(11 300 cal. yr BP). The sand unit at $2.53-2.51 \mathrm{~m}$ indicates wave action close to the threshold, suggesting that the seashore was still close to the lake.

A transition to marine conditions occurs between 2.45 and $2.40 \mathrm{~m}$, and we estimate the age of this transgression of the basin threshold to c. $9750 \mathrm{BP}$ (11 100 cal. yr BP). The diatom record in the interval $2.51-2.40 \mathrm{~m}$ suggests that the preceding regression prevented storm waves from reaching the basin. The length of the second marine phase is unknown due to the hiatus at $2.39 \mathrm{~m}$, but it must have ended prior to the isolation of Lake Neðstavatn.

Lake Nedstavatn. - The diatom record displays a beautiful isolation sequence, with the isolation taking place around $1.8 \mathrm{~m}$ (Fig. 3E). The regression of relative sea level below the basin threshold occurred within zone $\mathrm{N}-2$, and we date it to c. $9650-9600 \mathrm{BP}$ (10 900 cal. yr BP).

Open section. - The total dominance of freshwater diatoms in sample $A$ (Table 4) shows that relative sea level by $9050 \mathrm{BP}$ (10 $100 \mathrm{cal}$. yr BP) had fallen below $1.5 \mathrm{ma}$ a.s.l. The stratigraphic position of this sample in relation to the basal gravel (Fig. 4), which we interpret as a beach deposit, suggests that this happened 9200$9100 \mathrm{BP}$ (10 $200 \mathrm{cal}$. yr BP).

\section{The relative sea-level displacement curve}

All dated regressions and transgressions of basin thresholds were used to construct the curve of relative sea-level change shown in Fig. 6. In the same figure, we have also plotted the altitudes of lake thresholds and raised beaches (cf. Fig. 1), based on our levellings. Since it was impossible to elucidate any changes in isobase direction from the beach-ridge data, the presented curve is tentative, showing the average sea-level change in the area.

The earliest fixed point on our curve is the isolation of Lake Hraunsvatn. For the preceding period we know that Lake Torfadalsvatn was isolated prior to $11300 \mathrm{BP}$, and that relative sea level at an earlier stage stood at $65 \mathrm{~m}$ a.s.l., which we believe is the marine limit in this area, and created a beach ridge (A).

From our curve, it is clear that the overall regression was interrupted by two short-lived transgressions of around five metres amplitude. The first transgression occurred within RPAZ Skagi-3, i.e. during the Younger Dryas, or more precisely in the last part of that period. It is clear that this transgression resulted in short-lived brackish events in Lake Torfadalsvatn and Lake Hraunsvatn, and we suggest that it was connected to the build-up of beach ridge $B$ at $43-50$ $\mathrm{m}$ a.s.l. After a very rapid regression, the second transgression followed within RPAZ Skagi-4, i.c. in early Preboreal. This transgression was associated with the deposition of beach ridge $\mathrm{C}$ at $22.31 \mathrm{~m}$ a.s.l. in the area. It caused a change to marine conditions (and probably also the hiatus) in Lake Kollusátursvatn, but it did not reach Lake Geitakarlsvötn despite its proximity to ridge $C$. This could be explained by 
Fig. 7. Tentative calendaryear-based relative sea-level curve for northernmost Skagi. See text and Table 3 for details on the calendar-year chronology.

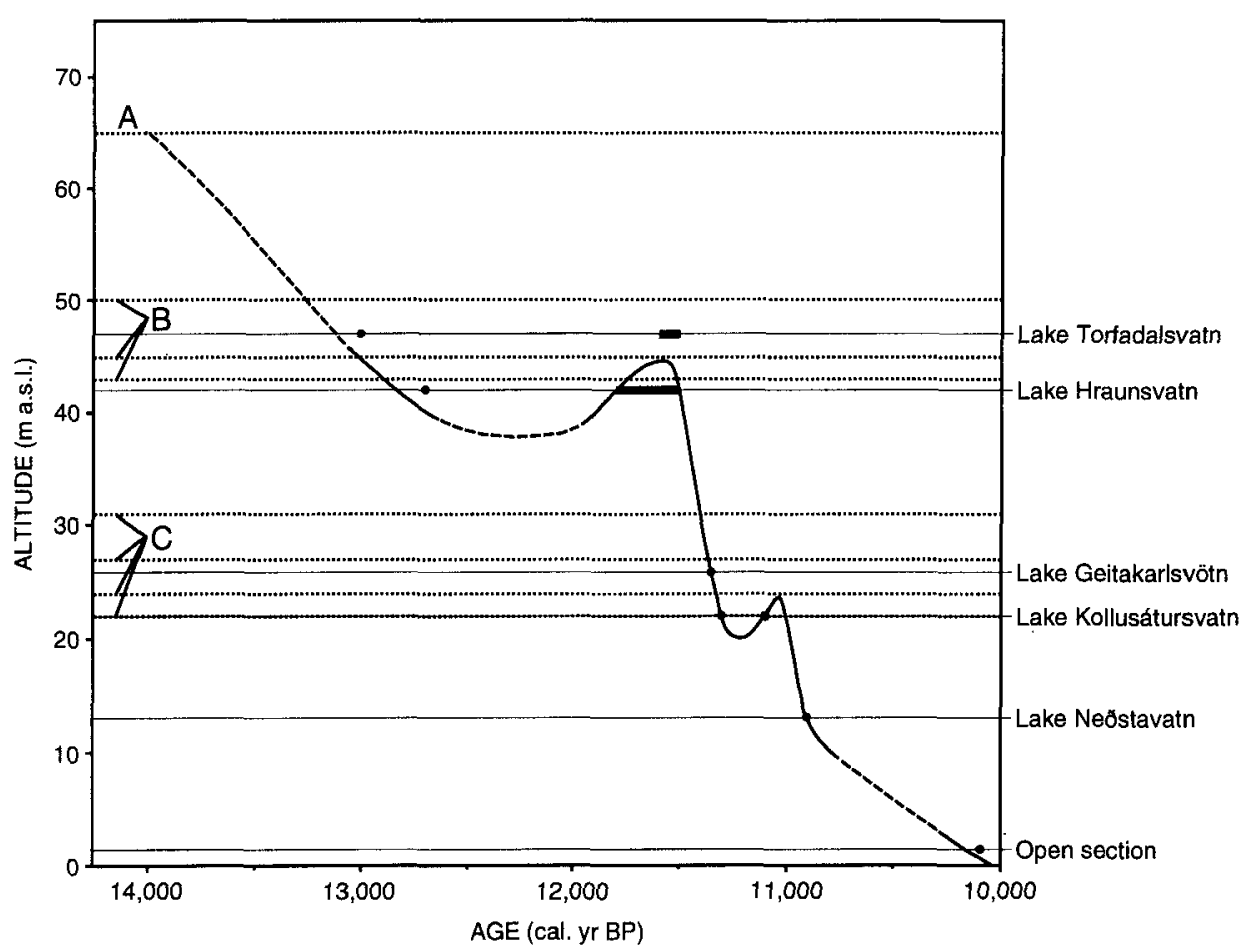

the higher elevation of the latter lake in combination with local differences in topography and fetch. This second transgression was followed by rapid regression, and relative sea level dropped below present-day sea level at $9000 \mathrm{BP}$.

\section{Discussion}

The generally large standard errors associated with our radiocarbon dates (Table 2) make it difficult to present a detailed reconstruction of relative sea-level changes based only on radiocarbon dating, but this was possible through the combination of radiocarbon dating, pollen stratigraphy, tephrochronology and the spatial relation between the investigated lake basins and the continuous beach ridges. The exact timing of the second transgression is, however, difficult to determine due to the weak age control and the hiatus in that part of the Lake Kollusátursvatn succession, but it is clear that it occurred several hundred years after the K-1/K-2 boundary at $9900 \mathrm{BP}$ (Fig. 3D) and prior to the isolation of Lake Neðstavatn, which took place shortly before $9600 \mathrm{BP}$ (Fig. 3E). The relatively large section of non-marine sediments between the sand layer at $2.53-2.51 \mathrm{~m}$ in Lake Kollusátursvatn (Fig. $3 \mathrm{D})$, which may be related to a storm event, and the marine sample at $2.40 \mathrm{~m}$ suggests that the second transgression was separated from the first isolation of Lake Kollusátursvatn by at least 100 years.
The marine limit at $65 \mathrm{~m}$ a.s.l. (ridge A in Figs. 1 and 6) at the northern coast of the Skagi peninsula is older than the onset of sedimentation in Lake Torfadalsvatn at c. $11300 \mathrm{BP}$ (Rundgren 1995). We tentatively relate the marine limit to a Bølling event of high relative sea levels on Iceland (Ashwell 1967; Ingólfsson 1988; Ingólfsson \& Norddahl 1994) and assign it an age of $>12000 \mathrm{BP}(>14000$ cal. yr BP).

We have a much better stratigraphic control of the relative sea-level changes for the period $11300-9100$ BP (13 000-10 200 cal. yr BP). During that time, the overall fall in the relative sea level was about $45 \mathrm{~m}$. The total isostatic uplift at northernmost Skagi, calculated as the sum of recorded shoreline displacement and concurrent eustatic rise (according to Fairbanks 1989) equals about $77 \mathrm{~m}$ during this period, corresponding to a mean absolute uplift rate of c. 3.5 $\mathrm{cm} \cdot{ }^{14} \mathrm{C} r^{-1}$. However, the uplift rate was not constant throughout the period, and the general regression was interrupted by two transgressions of around $5 \mathrm{~m}$ amplitude. Between the two transgressions, in the period $10000-9850 \mathrm{BP}$, relative sea level fell by c. 20 $\mathrm{m}$, corresponding to a shore displacement of $c .13$ $\mathrm{cm} \cdot{ }^{14} \mathrm{C} r^{-1}$. When an eustatic rise of about $3 \mathrm{~m}$ during the same period (Fairbanks 1989) is taken into account, a mean absolute uplift rate of $c .15 \mathrm{~cm} \cdot{ }^{14} \mathrm{C}$ $\mathrm{yr}^{-1}$ can be calculated for this regressional phase. Following the second transgression, i.e. in the period 9700-9100 BP, the mean absolute uplift rate was around $6 \mathrm{~cm} \cdot{ }^{14} \mathrm{C} \mathrm{yr}^{-1}$. 
The timing of the two recorded transgressions, i.e. late Younger Dryas and early Preboreal, coincides with known readvances of ice-sheet margins around Iceland (Ingólfsson \& Norddahl 1994), which suggests that the recorded transgressions primarily are expressions of crustal loading due to glacier expansion. Norddahl \& Ásbjörnsdóttir (1995) found evidence in western Iceland of transgressions in connection with Younger Dryas and early Preboreal glacier advances. On the basis of seven radiocarbon dates, they suggested that the early Preboreal marine transgression occurred about $9800 \mathrm{BP}$, which fits remarkably well with our estimate of the age of the sceond transgression on Skagi. The glacial history of the Skagi peninsula proper is poorly known, and we cannot with certainty relate the recorded transgressions to known ice margins on Skagi.

Although glacier readvances coincide with the observed transgressions, suggesting a glacioisostatic control on relative sea level, the second transgression could possibly also in part be explained by the combined effect of forcbulge migration following glacier retreat from the Younger Dryas marginal positions and increased hydroisostatic loading.

An interesting feature of our sea-level reconstruction is that the rapid uplift following the first transgression started well before the end of RPAZ Skagi-3 (Fig. 6), which was correlated to the Younger Dryas by Rundgren (1995). If glacial loadings/unloadings were the main contributors to the recorded transgressions/regressions, this implies that ice volume decreased already before the end of the Younger Dryas. Both Lake Trofadalsvatn and Lake Hraunsvatn show lithostratigraphies with a change to more organic sediments (gyttja clay) alrcady below the Skagi-3/ Skagi-4 boundary (Fig. $3 \Lambda-B$ ), which suggests that the Younger Dryas-Preboreal transition (cf. Björck et al. 1996) occurred shortly before the change in terrestrial pollen assemblage. Even if we regard this lithological change as reflecting a limnic response to Preborcal warming, ice-recession was initiated prior to the Younger Dryas-Preboreal transition. As Rundgren (1995) characterized the entire RPAZ Skagi-3 as deposited in a cold period, it is unlikely that the glacial unloading towards the end of the Younger Dryas was caused by increased melting. It was more likely to have been attributable to a glacial dynamic change connected to reduced accumulation, which would indicate that the Icelandic climate became drier towards the end of the Younger Dryas, or to enhanced calving of the inland ice sheet. The latter process may have been facilitated by the Younger Dryas readvance, leading to increasing water depth in the fjords. According to our loading/unloading hypothesis, deglaciation was interrupted by a short-lived phase of glacial growth in the earliest part of the Preborcal. A corresponding cold phase has been identified on northernmost Skagi through detailed organic carbon and pollen analysis of three of the present lake sequencies (Björck et al. in press). The rapid shifts between the recorded transgressions and regressions imply almost instantaneous crustal responses to glacier fluctuations.

This very dynamic behaviour of crustal and glacial responses must, however, be put into more realistic time frames. Clcarly, estimations of Late Weichselian early Holocene uplift rates are associated with considerable uncertainty when these are related to ${ }^{14} \mathrm{C}$ years. This is due to the fact that this period was characterized by large oscillations in atmospheric ${ }^{14} \mathrm{C}$ content (Kromer \& Becker 1993; Björck et al. 1996), which, for example, resulted in long ${ }^{14} \mathrm{C}$ plateaux followed by rapidly falling ${ }^{14} \mathrm{C}$ ages. Earlier attempts to discuss (c.g. Ingólfsson et al. 1995) or present (c.g. Bondevik et al. 1995) calendar-year-based Younger Dryas-Preborcal relative sca-level changes have been hampered by these problems. To overcome these obstacles, we related the sea-level events of each basin to calendar years using the ${ }^{14} \mathrm{C}$ calibration of Björck et al. (1996) (see above). The resulting relative sea-level displacement curve is shown in Fig. 7.

The mean absolute uplift rate between 11300 and $9100 \mathrm{BP}$ is c. $2.7 \mathrm{~cm}$. calendar $\mathrm{yr}^{-1}$, compared with $3.5 \mathrm{~cm} \cdot{ }^{14} \mathrm{C} \mathrm{yr}^{-1}$, which indicates a slower total uplift rate when 'real' years are used. Most of the Allerød Younger Dryas relative sea-level changes do not differ much between the two dating methods. The following rapid regression occurs during the time of the late Younger Dryas-early Preboreal ${ }^{14} \mathrm{C}$ plateau, and according to our estimations the time between the isolations of Lake Hraunsvatn and Lake Kollusátursvatn covers $c .200$ calendar years. This suggests an absolute uplift rate of $1112 \mathrm{~cm} \cdot \mathrm{cal} \mathrm{yr}^{-1}$, which may seem more realistic than the $15 \mathrm{~cm} \cdot \mathrm{yr}^{-1}$ obtained from the ${ }^{14} \mathrm{C}$ dating. With the calendar time-scale, the time-span for the following transgression/regression phase, until Lake Kollusátursvatn's final isolation, is also prolonged by c. 150 years, and the Preboreal transgression culminates at $c .11050$ calendar ycars BP. The regression from Kollusátursvatn down to the open section took 800 calendar years compared with $600{ }^{14} \mathrm{C}$ years. Bard et al.'s (1996) calendar-year-dated sea-level curve gives an absolute uplift rate of $c .3 \mathrm{~cm} \cdot \mathrm{cal}^{\mathrm{yr}}$ ' . This shows that there was a considerable isostatic slowdown already 500 1000 years after the period of maximum uplift. According to our estimations there are thus some major anomalies when the different time-scales are used, and it shows that these must absolutely be taken into account when early Holocene relative sea-level changes are discussed and analysed.

During the Weichselian maximum glaciation, the inland ice sheet of Iceland was drained towards the shelf on each side of the Skagi peninsula, through Skagafjörour and Húnaflói (Fig. 1), as indicated by the direction of glacial striae (Hoppe 1982; Th. Einarsson 1967, 1994). The area around the village of 
Blönduós, situated in the southwestern part of the Skagi peninsula, adjacent to Húnaflói (Fig. 1), was studied with respect to glacial landforms and raised beaches by Meyer \& Venzke (1987) and Moriwaki (1990). They recognized a number of successive recessional moraine ridges, as well as marine terraces and beach ridges associated with the moraines, and concluded that the sea stood at the marine limit in connection with a glacier advance. According to Meyer \& Wenzke (1987) the marine limit is found at 65-70 $\mathrm{m}$ a.s.l. in the area, and can be traced for about $10 \mathrm{~km}$ to the southeast of Blönduós. The glacier advance connected with the marine limit could not be dated, but Moriwaki (1990) suggested it to be of Younger Dryas age. We propose that the marine limit at $65-70 \mathrm{~m}$ a.s.l. in the Blönduós area is contemporaneous with raised beach ridge $B(43-50 \mathrm{~m}$ a.s.1.) at the northern coast of Skagi. If this is a correct correlation, the Younger Dryas marine level along the western coast of the Skagi peninsula rises on a transect from north to south by a gradient of $0.4-0.5 \mathrm{~m} \cdot \mathrm{km}^{-1}$. This is a lower value than reported for postglacial gradients of raised beaches in other parts of Iceland, which often are around $1 \mathrm{~m} \cdot \mathrm{km}^{-1}$ (Thorkelsson 1935; Norddahl 1983; Pétursson 1986; Ingólfsson 1987; Norðdahl \& Einarsson 1988; Sæmundsson 1995; Ingólfsson et al. 1995). As there is no continuous strandline along the western coast of Skagi, connecting the marine limit in the Blönduós area with ridge $\mathrm{B}$ at the northern coast, the calculated gradient is only tentative.

A second set of pronounced terraces, which postdates the moraine ridges in the Blönduós area, occurs at c. $45 \mathrm{~m}$ a.s.l. (Meyer \& Venzke 1987). We propose that it correlates to beach ridge $\mathrm{C}(22-31 \mathrm{~m}$ a.s.l.) on northernmost Skagi. If correct, the early Preboreal marine level on western Skagi rises on a transect from north to south by a gradient of $0.3-0.5 \mathrm{~m} \cdot \mathrm{km}^{-1}$.

Studies of peat deposits overlying beach ridges in the Blönduós area indicate that relative sea level had fallen to or below the present level by $9000 \mathrm{BP}$ (Moriwaki 1990) or 8500 BP (Meyer \& Venzke 1987), which fits well with our relative sea-level curve for northernmost Skagi (Fig. 6).

The glacial history of Skagafjörður, on the eastern side of the Skagi peninsula (Fig. 1), was studied by Vikingsson (1978). He concluded that during the Weichselian glaciation an ice stream drained the inland ice sheet through Skagafjörður, with tributary glaciers in the local highlands. Víkingsson concluded that relative sea level during the deglaciation was higher than at present, and glacial retreat was accelerated by calving. He described three major glaciofluvial delta deposits, all formed during the retreat of the ice stream, when relative sea level stood at c. $45 \mathrm{~m}$ a.s.l. at each site. The $45 \mathrm{~m}$ level is thus diachronous and indicates that isostatic recovery, in connection with a southward recession of the Skagafjörður ice margin, kept pace with a eustatic rise in sea level. Only the southernmost delta was considered by Vikingsson to be an ice-marginal deposit, but since no datable material was found in connection with it, the timing of the deglaciation of Skagafjörour is still not clear. We propose that the 45 $\mathrm{m}$ marine limit at the head of Skagafjörour correlates with the $45 \mathrm{~m}$ level in the Blönduós area and raised beach ridge $\mathrm{C}(22-31 \mathrm{~m}$ a.s.l.) on northernmost Skagi. This correlation implies that glacial retreat in Skagafjörour occurred in early Preboreal. The position of the ice margin in Skagafjörður during the regional Younger Dryas glacial advance (Ingólfsson \& Norddahl 1994) is still unknown.

\section{Conclusions}

In summary, from our investigations on northernmost Skagi, we conclude that:

1. The marine limit at the northern coast of Skagi at c. $65 \mathrm{~m}$ a.s.l. is older than $11300 \mathrm{BP}$, and we tentatively relate it to a Bølling event ( $>12000 \mathrm{BP}$ ) of high relative sea levels on Iceland.

2. There was an overall fall of $45 \mathrm{~m}$ in relative sea level at the northern coast of the Skagi peninsula between 113000 and $9100 \mathrm{BP}$, corresponding to an isostatic uplift of $77 \mathrm{~m}$. Regression below present sea level occurred at $9000 \mathrm{BP}$.

3. The overall regression was interrupted by two minor transgressions during late Younger Dryas and in early Preboreal. The Preboreal transgression phase is prolonged by 150 years when it is dated in calendar years.

4. Sea-level displacement was most rapid in the period between the two transgressions $(10000-9850$ BP), with a mean absolute uplift rate of $c .15 \mathrm{~cm} \cdot{ }^{14} \mathrm{C}$ $\mathrm{yr}^{-1}$ or $11-12 \mathrm{~cm} \cdot$ cal. $\mathrm{yr}^{-1}$.

5. The transgressions were most likely caused by increased ice volumes in the vicinity of the Skagi peninsula, probably by a combination of an expansion of small ice caps in the mountainous southern part of Skagi and readvances of the Icelandic inland ice-sheet margin.

6. Very high isostatic rebound rates combined with rapid shifts between transgressions and regressions reflect the extreme sensitivity of the Icelandic crust to loading and unloading by glacial ice. This is also shown by the considerably slowed-down Preboreal uplift rates following only 500-1000 years after the initial rapid emergence.

Acknowledgements. - This project was funded by the Icelandic Science Foundation, Kungliga Fysiografiska Sällskapet (Lund), Lunds Geologiska Fältklubb, the Swedish Natural Science Research Council (grants to Björck and Ingólfsson) and the European Commission through MAST III under the auspices of the ENAM II project (grants to Hafliðason). We express our thanks to Halldor Pétursson and Hörour Kristinsson at the Akureyri Museum of Natural History for valuable assistance during the reconnaissance phase of the project. Arni Hjartarson and the National Energy Authority, Reykjavík, are also gratefully acknowledged for their 
help with fieldwork in 1992. Ole Tumyr assisted with the scanning microscope analysis, and Ragnar Olafsson assisted in surveying the raised beaches in 1991.

\section{References}

Anundsen, K. 1985: Changes in shore-level and ice-front position in Late Weichsel and Holocene, southern Norway. Norsk Geografisk Tidsskrift 39, 205-225.

Ashwell, I. Y. 1967; Radiocarbon ages of shells in the glaciomarine deposits of western Iceland. The Geographical Journal 133, 4850 .

Bard, E., Arnold, M., Mangerud, J., Paterne, M., Labeyrie, L. Duprat, J., Mélières, M.-A., Sønstegaard, E. \& Duplessy, J.-C. 1994: The North Atlantic atmosphere-sea surface ${ }^{14} \mathrm{C}$ gradient during the Younger Dryas climatic event. Earth and Planetary Science Letters 126, 275-287.

Bard, E., Hamelin, B., Arnold, M., Montaggioni, L., Cabioch, G., Faure, G. \& Rougerie, F. 1996: Deglacial sea-level record from Tahiti corals and the timing of global meltwater discharge. $\mathrm{Na}$ ture $382,241244$.

Bároarson, G. G. 1928: Fornar sjávarminjar við Borgarfjörơ og Hvalfjörd [English summary: Old sea-deposits in Borgarfjörour and IVvalfjöröur]. Rit Visindafélags Islendinga $I, 116$ pp. Prentsmiðja Odds Björnssonar, Akureyri.

Berglund, B. E. 1966: Late-Quaternary vegetation in eastern Blekinge, south-eastern Sweden. A pollen-analytical study. Opera Botanica 12, Part 1, $180 \mathrm{pp}$

Birks. H. H., Gulliksen, S., Hallidason, H., Mangerud, J. \& Possnert, G. 1996: New radiocarbon dates for the Vedde Ash and the Saksunarvatn Ash from western Norway. Ouaternary Research $45,119-127$.

Björck, S. 1981: A stratigraphic study of Late Weichselian deglaciation, shore displacement and vegeatation history in south-eastern Sweden. Fossils and Strata 14, $1-93$.

Björck, S. \& Digerfeldt, G. 1982: Late Weichselian shore displacement at Hunneberg, southern Sweden, indicating complex uplift Geologiska Föreningens i Stockholm Förhandlingar 104, 132-155.

Björck, S., Ingólfsson, Ó., Hafliơason, H., Hallsdóttir, M. \& Anderson, N. J. 1992: Lake Torfadalsvatn: a high resolution record of the North Atlantic ash zone I and the last glacial-interglacial environmental changes in Iceland. Boreas 21, 15-22.

Björck, S., Kromer, B., Johnsen, S., Bennike, O., I Jammarlund, D., Lemdahl, G., Possnert, G., Rasmussen, T. L., Wohlfarth, B. Hammer, C. U. \& Spurk, M. 1996: Synchronized terrestrial atmospheric deglacial records around the North Allantic. Science $274,1155-1160$

Björck, S., Rundgren, M., Ingóll'sson, Ó. \& Funder, S.: The Preboreal oscillation around the Nordic Seas: terrestrial and lacustrine responses. Manuscript in press in the Joumal of Quaternary Sicince.

Bondevik, S., Mangerud, J., Ronnert, L. \& Salvigsen, O. 1995: Postglacial sea-level history of Edgeøya and Barentsøya, eastern Svalbard Polar Research 14, 153-180

Einarsson, Th, 1961: Pollenanalytische Untersuchungen zur spätund postglazialen Kilmageschichte Islands. Sonderveröffontlichungen des Geologischen Institutes der Universität Köln 6, 52 pp.

Einarsson, Th. 1963: Pollen-analytical studies on the vegetation and climate history of Iceland in late and post-glacial times. In Löve, A. \& Löve, D. (eds.): North Atlantic Biota and their History, 355 - 365. Pergamon Press, Oxford.

Einarsson, Th. 1967: Zu der Ausdehnung der weichselzeitlichen Vereisung Nordislands. Sondeveröffentichungen des Geologischen Instinutes der Universität Köln 13, 167-173.

Einarsson, Th. 1994: Geology of Iceland. Rocks and Landscape. 309 pp. Mál og Menning, Reykjavik.

Einarsson, Tr. 1959: Studies of the Pleistocene in Eyjafjordur, middle northern Iceland. Socictas Scientiarium Islandica 33, 1 66.
Fairbanks, R. G. 1989: A 17,000-year glacio-eustatic sea level record: influence of glacial melting rates on the Younger Dryas event and deep-ocean circulation. Nature 342, 637-642.

Grönvold, K., Óskarsson, N., Johnsen, S. J., Clausen, H. B., Hammer, C. U., Bond, G. \& Bard, E. 1995; Ash layers from Iceland in the Greenland GRIP ice core correlated with oceanic and land sediments. Earth and Plantary Science Letters 135. $149-155$.

Hafsten, U. 1960: Pollen-analytic investigations in south Norway. In Holtedahl, O. (ed.): Geology of Norway. Norges Geologiske Undersokelse 208, 434-462.

Hallsdóttir, M. 1987: Pollen analytical studies of human intuenee on vegetation in relation to the Landnam tephra layer in southwest Iceland. Lundqua Thesis 18,45 pp. Department of Quaternary Geology, Lund University, Lund.

Hendey, N. 1. 1964: An Introductory Account of the Smaller Algae of British Coastal Waters. Part V. Bacillariophyceae (Diatoms). 317 pp. Her Majesty's Stationery Office, London.

Hoppe, G. 1982: The extent of the last inland ice sheet of Iceland. Jökull 32, 3-11.

Hustedt, F. 1930 1959: Die Kieselalgen Deutschlands, Österreichs und der Schweiz unter Berüicksichtigung der übrigen Länder Europas sowie der angrenzenden Meresgebiete. In Rabenhorsts, L. (ed.): Kryptogamen-Flora, Band 7, Teil 1.2, 920+845 pp. Akademische Verlagsgesellschaft Geest \& Portig, K.-G., Leipzig.

Husted1, F. 1957: Die Diatomeenflora des Flußssystems der Weser im Gebiet der Hansestadt Bremen. Abhandlungen des Naturwissenschafilichen Vereins in Bremen 34, $181-440$.

Ingólfsson, $O$. 1987: Investigations of the Late Weichselian glacial geology of the lower Borgarfjördur region, western lceland. Lundqua Thesis 19, $4 \mathrm{pp}$. + IV app. Department of Quaternary Geology, Lund University, Lund.

Ingólfsson, O. 1988: Glacial history of the lower Borgarfjordur arca, western lceland. Geologiska Föreningens $i$ Slockholm Förhandlingar $110,293-309$.

lngólfsson, O. 1991: A review of the Late Weichselian and early Holocene glacial and environment history of Iceland. In Maizels. J. K. \& Caseidine, C. (eds.): Enwironmental Change in lceland. Past and Present, 13 29. Kluwer Academic Publishers, Dordrecht.

Ingólfsson, O. \& Norddahl, H. 1994: A review of the environmental history of Iceland, $130009000 \mathrm{yr}$ BP. Journal of Quaternary Science 9, $147-150$.

Ingolfsson, O., Norddahl, H. \& Haflidason, H. 1995: Rapid isostatic rebound in southwestern lceland at the end of the last glaciation. Borcas 24, $245-259$.

Jonsson, J. 1957: The Hoffellssandur, Part III: Notes on changes of sea-level in Iceland. Goografiska Annaler .39, 143.212.

Kjartansson, G., Thorarinsson, S. \& Einarsson, Th. 1964: ${ }^{14} \mathrm{C}-\mathrm{al}$ dursákvarơanir á sýnishornum varðandi islenzka kvarterjarðfraðo [English summary: ${ }^{14} \mathrm{C}$ datings of Quaternary deposits in Iceland]. Náttirufradingurim 34, 97-145.

Kolbe, R. W. 1927: Zur Ökologie, Morphologie und Systematik der Brackwasser-Diatomeen. Dic Kieselalgen des Sperenberger Salzgebietes. Pflanzenforschung 7, $1-146$.

Krammer, K. \& Lange-Bertalot, H. 1986-1991: Bacillariophyceac. Teil 1-4. In Ettl, H., Geoloff, J., Heynig, H. \& Mollenhauer, D. (eds.): Süsswasserflora von Mitteleuropa 2,876, +596+576+437 pp. Gustav Fischer Verlag, Stuttgart.

Kromer, B. \& Becker, B. 1993: German oak and pine ${ }^{14} \mathrm{C}$ calibration. Radiocarbon $35,125-135$.

Kvamme, T., Mangerud, J., Furnes, H. \& Ruddiman, W. F. 1989 Geochemistry of Pleistocene ash zones in cores from the North Atlantic. Norsk Geologisk Tidsskrift 69, 251-272.

Mangerud, J., Furnes, H. \& Jóhansen, J. 1986: A 9000-year-old ash bed on the Faroe Islands. Quaternary Research 26, 262--265.

Meyer, H.-H. \& Venzke, J.-F. 1987: Deglaciation and sea-level changes in the vicinity of Blönduos, northern locland, in late glacial and early Holocene times. A preliminary report. Norden 4 . 4764 . 
Moriwaki, H. 1990: Late- and postglacial shoreline displacement and glaciation in and around the Skagi peninsula, northern Iceland. Geographical Reports of Tokyo Metropolitan University $25,81-97$.

Norodahl, H. 1983: Late Quaternary stratigraphy of Fnjóskadalur central north Iceland, a study of sediments, icc-lake strandlines, glacial isostasy and ice-free areas. Lundqua Thesis 12,78 pp. Department of Quaternary Geology, Lund University, Lund.

Norődahl. H. \& Einarsson, P. 1988: Hörfun jökla og sjávarstöoubreytingar i isaldarlok á Austfjöroum [English summary: Late Weichselian deglaciation and sea-level changes in east and southeast Iceland]. Nätürufredingurim 58,59-80.

Norodahl. H. \& Ásbjörnsdóttir, L. 1995: Ísaldarlok í Hvammsfirơi. In Hróarsson, B., Jónsson, D. \& Jónsson, S. S. (eds.): Evjar i eldhafi, 117 131. Gott Mál, Reykjavík.

Patrick, R. \& Reimer, C. W. 1966-1975: The diatoms of the United States, Vols. 1-2. Monographs of The Academy of Natural Sciences of Philadelphia $13,688+213 \mathrm{pp}$.

Pétursson, 11. G. 1986: Kvartergeologiske undersøkelser på VestMelrakkaslélta, Nordøst-Island. 157 pp. Unpublished Cand, Real. Thesis. Universitetet i Tromsø, Tromsø.
Rundgren, M. 1995: Biostratigraphic evidence of the AllerødYounger Dryas - Preboreal oscillation in northern Iceland. Ouaternary Research 44, 405-416.

Sxmundsson, Th. 1995: Deglaciation and shoreline displacement in Vopnafjördur, northeastern Iceland. Lundqua Thesis 33, 106 pp. Department of Quaternary Geology, Lund University, Lund.

Stuiver. M. \& Reimer, P. J. 1993: Extended ${ }^{14} \mathrm{C}$ data base and revised ${ }^{14} \mathrm{C}$ calibration program. Radiocarbon $35,215230$.

Thorarinsson, S. 1956: Mórinn i Seltjörn [English summary: The submerged peat in Seltjörn]. Nattumufradingurinn 26, 179-193.

Thorkelsson, Th. 1935: Old shore-lines in Iceland and isostasy. Societas Scientiariam Islandica, Greinar I, 1-7.

Thors, K. \& Boulton, G. S. 1991: Deltas, spits and littoral terraces associated with rising sea level: Late Quaternary examples from northern Iceland. Marine Geology 98, 99 112.

Thors, K. \& Helgadóttir, G. 1991: Evidence from south west Iceland of low sea level in early Flandrian times. In Maizels, J. K. \& Caseldine, C. (eds.): Environmental Change in Iceland: Past and Present, 93 104. Kluwer Academic Publishers, Dordrecht.

Vikingsson, S. 1978: The deglaciation of the southern part of the Skagafjördur district, northern Iceland. Jökull 28, 1-17. 